\title{
Season affects fire behavior in annually burned humid savanna of West Africa
}

\author{
Aya Brigitte N'Dri ${ }^{*}{ }^{*}$, Tionhonkélé Drissa Soro ${ }^{1}$, Jacques Gignoux ${ }^{2}$, Kanvaly Dosso ${ }^{1}$, Mouhamadou Koné3

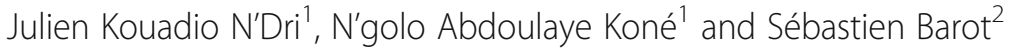

\begin{abstract}
Background: Fire is important for the maintenance of African savanna ecosystems, particularly humid savanna. Despite the importance of fire behavior to our understanding of fire's ecological effects, few studies have documented fire behavior and its determinants in humid West African savannas and, in particular, whether fire behavior depends on season of the year. We analyzed fire behavior in the Guinean savanna of Lamto (Ivory Coast) during a 4-year field experiment. The fire regimes tested consisted of three different burning seasons: early-season fire, mid-season fire, and late-season fire. Nine 0.5 ha plots were burned annually to determine the rate of spread and fire intensity. Fuel characteristics and weather conditions were measured to assess their impact on fire behavior.

Results: Understory grass height, total fresh fuel load, and moisture content had greater values in early-season fire than in mid-season and late-season fire. The rate of spread and intensity of both mid-season fire $\left(0.14 \pm 0.03 \mathrm{~m} \mathrm{~s}^{-1}\right.$ and 3920 $\pm 740 \mathrm{~kW} \mathrm{~m}^{-1}$, respectively) and of late-season fire $\left(0.12 \pm 0.02 \mathrm{~m} \mathrm{~s}^{-1}\right.$ and $3134 \pm 482 \mathrm{~kW} \mathrm{~m}^{-1}$, respectively) were significantly greater than those of early-season fire $\left(0.04 \pm 0.01 \mathrm{~m} \mathrm{~s}^{-1}\right.$ and $1416 \pm 252 \mathrm{~kW} \mathrm{~m}^{-1}$, respectively). The best predictors of fire behavior were fuel moisture content and air humidity; these two explanatory variables were the sole significant predictors for fire intensity, rate of fire spread, and flame height.

Conclusions: Given that there is no difference between intensity of mid-season and late-season fire, we suggest that the generally reported higher impact of late-season fire on trees in the West African humid savannas is due not to fire intensity per se, but rather to a more sensitive phenological stage of trees (e.g., leafless in mid-season), and to a longer time of exposure to lethal temperatures $\left(>60^{\circ} \mathrm{C}\right)$ in the late dry season. These data provide important insights into fire behavior in the Guinean savanna-forest mosaic ecoregion, informing fire management.
\end{abstract}

Keywords: burning season, fire severity, fuel loads, Guinean savanna

\footnotetext{
* Correspondence: ndri.brigitte@yahoo.fr; ndribrigitte.sn@univ-na.ci

${ }^{1}$ UFR des Sciences de la Nature, Station d'Ecologie de Lamto/CRE, Pôle de Recherche Environnement et Développement Durable, Université Nangui Abrogoua, 02 BP 801, Abidjan 02, Côte d'Ivoire

Full list of author information is available at the end of the article
} 


\section{Resumen}

Antecedentes: El fuego es un disturbio importante para el mantenimiento de los ecosistemas de sabana africanos, particularmente de la sabana húmeda. A pesar de la importancia del comportamiento del fuego para entender sus efectos ecológicos, pocos estudios han documentado el comportamiento del fuego y sus determinantes en las sabanas húmedas del oeste de África y, en particular, si este comportamiento depende de la estación del año. Analizamos en comportamiento del fuego en la sabana de Lamto (Costa de Marfil) en Guinea durante 4 años de experimentos a campo. Los regímenes de fuegos analizados consistieron en tres estaciones de incendios: fuegos ocurridos durante la estación temprana, la media y la tardía. Nueve parcelas de 0,5 ha fueron quemadas anualmente para determinar la velocidad de propagación y la intensidad del fuego. Las características de los combustibles y las condiciones atmosféricas fueron medidas para determinar su impacto en el comportamiento del fuego.

Resultados: La altura de los pastos en el sotobosque, el peso verde de la carga total de combustible, y el contenido de humedad tuvieron mayores valores en la estación temprana de incendios en comparación con las estaciones media y tardía. La velocidad de propagación e intensidad del fuego tanto de la estación media $\left(0,14 \pm 0,03 \mathrm{~m} \mathrm{~s}^{-1}\right.$, y $3920 \pm 740 \mathrm{~kW} \mathrm{~m}^{-1}$, respectivamente) como de la estación tardía $\left(0,12 \pm 0,02 \mathrm{~m} \mathrm{~s}^{-1}\right.$ y $3134 \pm 482 \mathrm{~kW} \mathrm{~m}^{-1}$, respectivamente), fueron significativamente mayores que aquellos obtenidos para la estación temprana $(0,04 \pm$ $0,01 \mathrm{~m} \mathrm{~s}^{-1}$ y $1416 \pm 252 \mathrm{~kW} \mathrm{~m}^{-1}$, respectivamente). Los mejores predictores del comportamiento del fuego fueron la humedad del combustible y la humedad del ambiente; estas dos variables explicativas fueron las únicas significativas para predecir la intensidad del fuego, la velocidad de propagación, y la altura de llama.

Conclusiones: Dado que no hay diferencias en intensidad entre fuegos ocurridos en las estaciones medias y tardías, sugerimos que el mayor impacto que se reporta generalmente para incendios ocurridos durante la estación tardía en árboles de las sabanas húmedas del oeste de África, no es debido al impacto de la intensidad del fuego de por sí, sino a un estado fenológico más sensible (i.e., sin hojas durante la estación media de incendios), y a una exposición más prolongada a temperaturas letales $\left(>60^{\circ} \mathrm{C}\right.$ ) durante la estación tardía seca. Estos datos contribuyen de manera importante al conocimiento sobre el comportamiento del fuego en los mosaicos de sabanas y bosques de la ecoregión de Guinea y como información para el manejo del fuego.

\section{Background}

Almost every vegetation type in the world occurs in balance with a particular fire regime. Fire regimes are increasingly controlled, if not driven, by humans (Gill and Allan 2008), yielding dramatic changes in many ecosystems worldwide, to the point that managers of protected areas sometimes have to revert to past fire regimes in order to maintain targeted ecosystem services or biodiversity (Swetnam et al. 1999). The spatio-temporal patterns of heat energy release are called fire behavior (Trollope 1983). Fire behavior is generally described by fire intensity, rate of spread, flame height, residence time, and surface temperature (Williams et al., 1998, Savadogo et al. 2007, Fontaine et al. 2012). It is influenced by a wide range of variables such as fuel characteristics, burning season, and weather conditions (Trollope et al. 2002). Fire behavior directly affects savanna plants (e.g., scorching, topkill, death; N'Dri et al. 2011, Werner and Prior 2013, Smit et al. 2016). Fuel loads are generally higher with longer time intervals between fires and thus fire frequency becomes the primary driver of fuel accumulation and is a major factor in wooded ecosystems, where plants are long-lived. Fuels may accumulate over many years until the accumulated dead biomass reaches balance with decomposition. As a result, at least for short fire return intervals, a strong negative correlation between fuel load and fire frequency is expected.

When fire frequency is very high, the season of the fire plays a significant role on fuel quantity (Govender et al. 2006). This is the case in most savanna and grassland ecosystems, where fire return intervals are commonly in the range one to ten years (van Wilgen et al. 2003). Whereas the effect of fire frequency on fire intensity is well documented (e.g., Govender et al. 2006, Robertson and Hmielowski 2014), only a few studies have examined very high fire frequency and the impact of fire season on fire intensity (e.g., van Wilgen et al. 2007; Rissi et al. 2017). Moreover, quite recently, Prichard et al. (2017) reviewed fire regimes across the world's major bioregions and pointed out the relative scarcity of literature on these subjects in African savannas.

In a review of the experiments of the Kruger National Park, South Africa, van Wilgen et al. (2007) found that the most marked effects on vegetation were found in extreme treatments (annual burning, burning in the summer wet season, or long periods of fire exclusion), and were greater in areas of higher rainfall. Among the African savannas, the most extreme fire conditions (annual burning, high rainfall) occur in the Guinean forest 
-savanna mosaic ecoregion, extending over $670000 \mathrm{~km}^{2}$ in West Africa (Kier et al. 2005). In this area, fire return interval is generally between 1 and 3 years, with $21 \%$ of this area burned annually (Innes 1972, Dwomoh and Wimberly 2017). Annual rainfall is in the range of 1000 $-1600 \mathrm{~mm} \mathrm{yr}^{-1}$ (L'Hôte and Mahé 2012), yielding very high grass production (Gignoux et al. 2006). At the continental scale, the Guinean ecoregion is a transition zone from forest to savanna; but at the local scale, forest and savannas do not mix: they form a mosaic of savannas dotted with forest islands and fringed by gallery forests following the hydrologic network. In the field, the transition between the two ecosystems is very sharp (often occurring in as little as four meters); both the physiognomy and the respective floras are different (Spichiger and Pamard 1973). Fires almost never enter the forests, but near-annual fires are responsible for maintaining the adjacent open vegetation (Vuattoux 1976, Louppe et al. 1995). Nevertheless, significant woody plant encroachment into this area has been reported despite the very frequent and intense fire regime (Gautier 1990, Dauget and Menaut 1992, Hochberg et al. 1994).

It is well known from field studies that late-season fires (occurring at the end of the long dry season, or even at the start of the long wet season) are more harmful to trees and can better control tree populations than are early-season fires (Louppe et al. 1995, Gignoux et al. 2006, Laris et al. 2017). Studies undertaken in Guinean savanna of West Africa (Aubréville 1953, Brookman-Amissah et al. 1980, Swaine et al. 1992, Louppe et al. 1995) explored the impacts of fire treatments on vegetation dynamics but did not analyze fire behavior parameters. Overall, we do not know whether the more severe effect of late fires on trees is due to a higher fire intensity or a higher sensitivity of trees to fire due to their phenological stage. It is therefore of primary importance, in the first instance, to measure how fire intensity varies with fire season.

To this end, we conducted a 4-year field experiment with three different fire treatments in a Guinean savanna to study fire behavior (including intensity) in response to fire season. Our aim was to test the effect of fire season on fire intensity in an extreme situation in which fire frequency is at its maximum, with one fire each year, as well as to explore a range of variables that determine fire behavior in general. The study addressed the following questions:

1. Do fire behavior, fuel characteristics, and weather conditions differ among fires set in early, mid, and late dry seasons?

2. Is late-season fire (occurring at the end of dry season), more intense than early- and mid- season fires?

3. Which weather and fuel characteristics predict fire behavior?

\section{Methods}

Study site

The study site was the Lamto Reserve (central Ivory Coast, extending from $6^{\circ} 9^{\prime} \mathrm{N}$ to $6^{\circ} 13^{\prime} \mathrm{N}$, and from $-5^{\circ}$ $15^{\prime} \mathrm{W}$ to $\left.-4^{\circ} 57^{\prime} \mathrm{W}\right)$, a 2500 ha area of typical Guinean forest-savanna mosaic devoted to scientific research since 1962 (Abbadie et al. 2006). The average annual rainfall is about $1200 \mathrm{~mm}$ (Pagney 1988). The climate is sub-equatorial with four seasons based on monthly rain: a long rainy season from mid March to July, a short dry season in August, a short rainy season from September to mid November, and a long dry season from mid November to mid March. The shorter dry season has significant interannual variations in the date (August, September, or October) and duration (0 to 2 months). Fires in the Lamto Reserve are set by managers in the middle of the long dry season (mid-season fire), following practices of local populations.

The main savanna type is a shrubby savanna with tree cover between 7\% and 62\% (Gautier 1990). The savanna is dominated by three species of Andropogoneae grasses: Andropogon ascinodis C. B. Cl., Andropogon canaliculatus (Schumach.), and Andropogon schirensis (Hochst. ex A. Rich). Annual aboveground grass net primary production can be as high as $20 \mathrm{t} \mathrm{ha}^{-1} \mathrm{yr}^{-1}$ (dry mass; Gignoux et al. 2006).

\section{Experimental set-up and fire treatments}

This study was conducted on three $230 \mathrm{~m} \times 120 \mathrm{~m}$ blocks of shrubby savanna, each separated from the surrounding similar savanna by a $10 \mathrm{~m}$ wide firebreak, and distant from each other by a few kilometers (Fig. 1). Each block was divided into three $100 \mathrm{~m} \times 50 \mathrm{~m}$ plots separated from each other by $30 \mathrm{~m}$ wide firebreaks. Each plot in a block received one of three fire treatments in a full factorial design: (1) early-season fire at the start of the long dry season ( 18 November); (2) mid-season fire at the middle of the long dry season ( 18 January); and (3) late-season fire at the very end of the long dry season ( 15 March) (Fig. 2). On each plot, the designated fire treatment was applied four times from 2013 to 2017. All blocks were located on flat ground to eliminate the influence of slope. All plots had experienced annual mid-season fire for at least 50 years before the experiment.

\section{Fuel characteristics}

Fuel consisted primarily of grass and tree leaf litter. Fuel characteristics were described by the following variables before fires were applied: fuel load $\left(\mathrm{kg} \mathrm{m}^{-2}\right)$, moisture content (\%), and grass height $(\mathrm{cm})$. Fuel was collected on ten $1 \mathrm{~m}^{2}$ quadrats per plot shortly (minutes) before burning. Fuel was separated into litter (fallen dead grass and tree leaves) and standing fuel (standing grass and stems), and immediately weighed for fresh mass. Samples were oven-dried at 


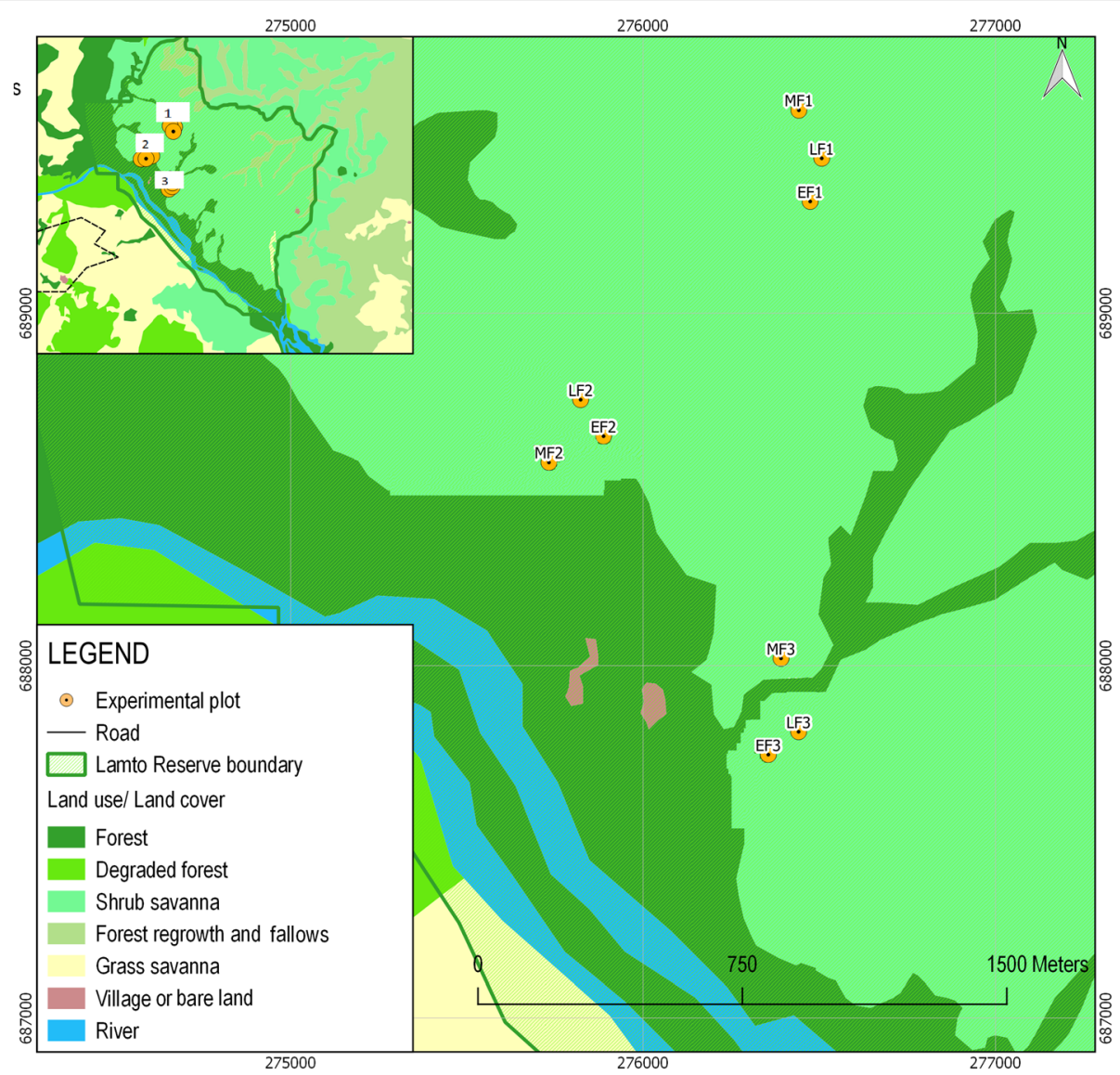

Fig. 1 Location of the study site and distribution of plots in the landscape. 1, 2, and 3: experimental blocks. MF1, LF1, and EF1: mid-season fire, late-season fire, and early-season fire plots in block 1, respectively

$80{ }^{\circ} \mathrm{C}$ to constant weight and weighed for dry mass. Moisture content was then calculated. Grass cover height $(\mathrm{cm})$ was determined as the average vertical distance from the ground to the tip of the shoot of 50 randomly selected points.

\section{Fire behavior}

Fire was ignited with a dry palm leaf along the shorter side of each plot in the direction of the wind to rapidly establish a fire-line and ensure linear ignition. All burns were conducted in the morning (1000 to 1100 hours) on the same day, in order to ensure similarity of fuel moisture levels and weather conditions (e.g, wind, air humidity, and temperature). We characterized fire behavior using six variables: rate of spread $\left(\mathrm{m} \mathrm{s}^{-1}\right)$, fire intensity $\left(\mathrm{kW} \mathrm{m}^{-1}\right)$, fire maximal temperature $\left({ }^{\circ} \mathrm{C}\right)$, residence time above $60{ }^{\circ} \mathrm{C}(\mathrm{s})$, flame height $(\mathrm{m})$, and combustion efficiency (\%).

The rate of spread was determined by using stop watches to record the time it took for a flame line to reach poles positioned every $10 \mathrm{~m}$ on both sides of each plot.
Fire intensity (I) was estimated using Byram's (1959) equation:

$$
I=W H R
$$

where $W\left(\mathrm{~kg} \mathrm{~m}^{-2}\right)$ is the mass of fresh fuel consumed; $H$ is the heat yield of the fuel, which, for grass fuel, $16890 \mathrm{~kJ} \mathrm{~kg}^{-1}$ is the recommended value (Trollope $1983)$; and $R\left(\mathrm{~m} \mathrm{~s}^{-1}\right)$ is the rate of spread.

The fire residence time was defined as the time during which air temperature at ground level, measured with a thermocouple, was above $60{ }^{\circ} \mathrm{C}$-the commonly accepted lethal temperature for most plant cells (Daniell et al. 1969). We used self-built synchronized fire temperature recorders (SFTRs) to measure this time. Each SFTR was composed of a thermocouple (type $\mathrm{K} 250 \mathrm{~mm}$ steel probe, 0 to $1100{ }^{\circ} \mathrm{C}$ range) connected to a Raspberry $\mathrm{Pi}$ nano-computer (https://www.raspberrypi.org/), plus batteries. Prior to setting fires, the SFTRs were synchronized by sending a "start" signal prior to burying them in the plots, with only the top 


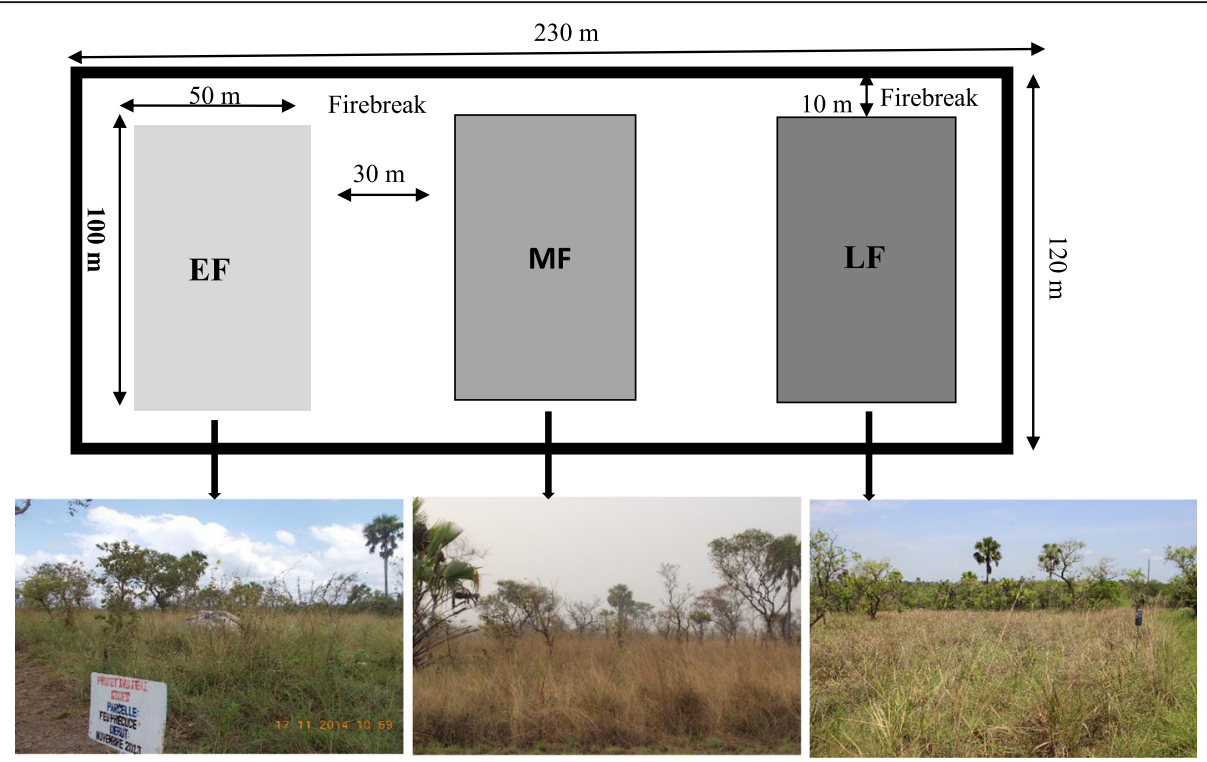

Fig. 2 Experimental set-up and fuelbed the day before each fire in 2014. EF: early-season fire, MF: mid-season fire; LF: late-season fire.

$10 \mathrm{~cm}$ of the thermocouple probe protruding from the ground. They were placed at the ends of equilateral triangles that had sides $20 \mathrm{~m}$ in length. After the fires, the time series of temperatures were downloaded from the STFRs and residence times were computed from those data.

Flame height (m) and fuel consumption (\%) were measured as post-fire indices of fire intensity and fire severity, respectively. Intensity is a function of the energy released by a fire front, while severity refers to the impact of fire on vegetation.

Flame height was measured on each plot after each fire using 10 iron poles, each of $4 \mathrm{~m}$ height, on which $5 \mathrm{~cm}$ long pieces of paper tape had been placed every $20 \mathrm{~cm}$. The flame height was equal to the maximum height where the paper was burned. The 10 poles on each plot were distributed randomly; heights were averaged over the ten poles for each plot for further analysis.

Immediately after each experimental fire, the residual unburned fuel in each plot from 10 random quadrats of 1 $\mathrm{m}^{2}$ was sampled, dried, and weighed, using techniques that were similar to those for the pre-fire samples. For each plot and fire, we used the average values of post-fire mass and pre-fire mass to estimate combustion efficiency (\%).

\section{Weather}

During each fire, wind speed $\left(\mathrm{m} \mathrm{s}^{-1}\right)$, air temperature $\left({ }^{\circ} \mathrm{C}\right)$, and relative humidity (\%) were recorded every five minutes, similar to methods of Kidnie and Wotton (2015), using an in situ automatic weather station (reference number SM55PRO; Inovalley, Pontoise, France) placed at $2 \mathrm{~m}$ aboveground, in the fire break between two adjacent plots. The recorded values were averaged over the period of fire propagation for each plot.

\section{Statistical analyses}

We analyzed data using $\mathrm{R}$ software ( $\mathrm{R}$ Development Core Team 2014). Mixed-effect models (lmer $R$ function) were developed to analyze the responses of fire behavior parameters (rate of spread, fire-line intensity, maximum temperature, residence time above lethal temperature, flame height, and combustion efficiency), as well as the relative importance of pre-burn fuel characteristics (grass height, fuel loads, and fuel moisture contents), and weather parameters during fires (air humidity, air temperature, and wind speed) relative to three explanatory variables: season (3 seasons), year (4 years) and plot (9 plots). Season was the fixed effect, while year and plot were treated as crossed random effect. We simplified the models by eliminating non-significant random effects, based on $F$-tests (they were exact tests because the experimental design was balanced). A Tukey multiple comparison test (HSD) was used to compare the different modalities of significant fixed effects.

For the effect of fuel and weather variables on fire behavior, we used mixed-effect multiple regression models (averages of fuels and weather parameters for each site and fire had been used to describe the sites and weather; these parameters did not vary at the individual plot level). Final models were selected using a stepwise procedure based on minimum Akaike Information Criterion estimation. Year and plot were again treated as crossed random effects.

\section{Results}

Fuel characteristics, weather conditions, and fire behavior across the seasons

Total fresh fuel load $\left(\mathrm{kg} \mathrm{m}^{-2}\right)$ and its moisture content were significantly greater in the early dry season than in 
the mid and late dry seasons. There was no significant difference in fuel loads between mid and late dry seasons. The height of the grassy understory decreased significantly from early to late dry season (Fig. 3, Table 1). Significant year random effects occurred for both total fuel load and grass height (Table 1).

Wind speed varied with year (78\% of variance explained by the random effect in the complete model; Table 1) and increased from early-season fire to late-season fire. Air temperature did not vary with fire season. Relative air humidity also varied with fire season, with a higher value in early-season fire (Fig. 3, Table 1).

All fire behavior variables except residence time above $60{ }^{\circ} \mathrm{C}$ showed the same pattern of response to fire season: their values were lower during the early-season fire than during mid-season and late season fires. There were no differences in the variables between mid-season fire and late-season fire. The fire residence time was highest in late-season fire and lowest in mid-season fire. Early-season fire presented the middle value. The only significant random effect (plot) was for combustion efficiency (Fig. 3; Table 1).

\section{Fire behavior: explanatory models}

Fire intensity $(\log I)$, rate of spread $(\log r)$, and flame height $(H)$ all decreased with fuel moisture content, and air humidity, explaining 55,63 , and $64 \%$ of the variability in these three aspects of fire behavior, respectively. Fire maximum temperature $(T)$ decreased with fuel moisture content, air humidity, and grass height (explaining $45 \%$ of the variation). Fire residence time above $60{ }^{\circ} \mathrm{C}$ $(R t)$ increased with fuel moisture content, air humidity, and air temperature, and decreased with fuel load (explaining $51 \%$ of the variation). Combustion efficiency (C) decreased with grass height (explaining $34 \%$ of the variation; Table 2).

As for explanatory variables, fuel moisture content was a very important $(P<0.001)$ for three of the six variables that describe fire behavior, and somewhat important $(P<0.10)$ in a fourth (Table 2$)$. Air humidity was an important explanatory variable $(P<0.01$ and $P<0.05)$ for four of the six variables describing fire behavior, and somewhat important $(P<0.10)$ in a fifth. These two explanatory variables were the sole significant predictors for fire intensity, rate of fire spread, and flame height. They also appeared in models for fire maximum temperature (plus grass height) and for fire residence time $>60^{\circ} \mathrm{C}$ (plus fuel load and air temperature; Table 2).

Grass height was a significant predictor $(P<0.05)$ of only one response variable (combustion efficiency), but also a weak inclusion in the model for fire maximum temperature. Fuel load was a significant predictor $(P<0.01)$ only in the model for fire residence time $>60{ }^{\circ} \mathrm{C}$ (Table 2).

\section{Discussion}

\section{Seasonal changes in fuel and fire characteristics}

There are few studies of the impact of season on fuel and fire characteristics in humid savannas anywhere in the world; comparisons can yield important insights for savanna ecosystem management. The results of our study are consistent with findings of Williams et al. (1998) in Northern Australia, and of Higgins et al. (2000) and van Wilgen et al. (2003) in South Africa that showed a decrease in moisture content as the dry season progresses. We also confirmed results from Rissi et al. (2017) in Brazil that showed that the dry fuel load does not change during the dry season.

Fuel loads in the present study at Lamto Reserve are higher than those previously reported for other African savannas-about five times greater than those of a Sudanian savanna of Burkina Faso (Savadogo et al. 2007), and about ten times greater than in Chad (Guiguindibaye et al. 2013). These high fuel loads most likely explain the higher fire intensity we recorded, compared to these savannas (Savadogo et al. 2007; Guiguindibaye et al. 2013). Frost et al. (1986) concluded that fire is more intense in humid savannas than in dry savannas due to differences in water availability that lead to differences in grass biomass (i.e., fuel loads).

Based on fire intensity classes defined by Morrison (2002), in Lamto Reserve, early-season fire can be considered low-intensity fire, and mid-season and late-season fires as high-intensity fires. In our study, both the rate of spread and intensity of fires increased as the dry season progressed. Flame height followed the same trend, and can be considered a good indicator of fire intensity, as was suggested by Burrows (1995), Williams et al. (1998), and Morrison (2002).

The fact that fire maximum temperature was lower during the early-fire season than during the mid- and late-season fires of our study is consistent with the results for different seasons reported by Sidzabda et al. (2010) for the same three fire seasons in a Sudanian savanna of Burkina Faso. The maximum fire temperature recorded in Lamto Reserve, however, is three times higher than that observed in both Laba State (Sidzabda et al. 2010) and Tiogo (Savadogo et al. 2007) in Burkina Faso. These differences in the maximum fire temperature is certainly due to the highest fire intensity in Lamto Reserve.

\section{Prediction of fire characteristics with fuel and weather characteristics}

Fuel characteristics and fire behavior of our study were comparable to those reported by Afelu and Kokou (2015) in the transition zone between the Guineo-Congolese and the Sudanian zones of Togo. The fuel loads in our humid savanna of Lamto Reserve were higher than those 

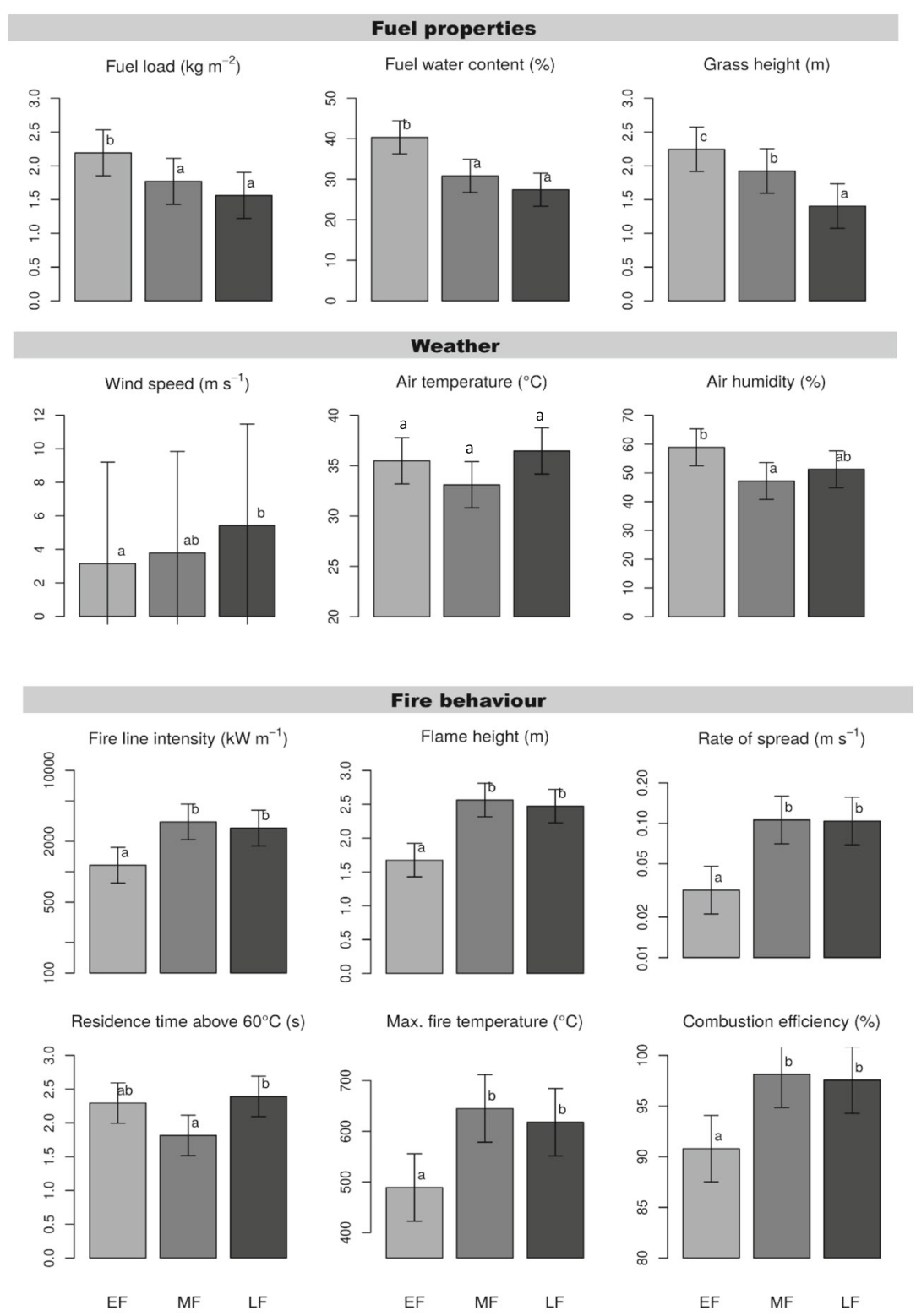

Fig. 3 Fire behavior, fuel characteristics, and weather parameters for the 2013-2017 period under the early-season fire (EF), mid-season fire (MF), and late-season fire (LF) treatments. Letters (a, b, and c) indicate groups of non-significantly different values at the $95 \%$ level according to fire regime (Tukey HSD post-hoc tests). Max. = maximum

measured in the humid savannas of Northern Australia (Williams et al., 1998) and in somewhat drier savannas of South Africa (van Wilgen et al., 1985), yet in Lamto Reserve, the rate of fire spread was slower and the intensity of fire was lower than those reported for early-season and late-season fires in those savannas. The difference in fire behavior could be due to the lower fuel moisture in Northern Australia and South Africa due to the single, much longer dry season. In Northern Australia, the very low moisture content of the fuel and the very dry air create favorable conditions for very rapid fire spread and higher fire intensity (Anderson and Anderson 2010, Fontaine et al. 2012). The comparison suggests that fuel moisture content is one of the main factors influencing fire behavior, as indicated by the fact that fuel moisture is the most common and significant explanatory variable predicting various descriptors of fire behavior in our study. Our results are also consistent with those of Govender et al. (2006), who observed a doubling of fire intensity when fuel moisture decreased three-fold. In our study, we observed the doubling of fire intensity when 
Table 1 Response of fire behavior, weather, and fuel variables to fire season (fixed effects), plot, and year (crossed random effects)

\begin{tabular}{|c|c|c|c|c|c|c|c|c|}
\hline \multirow[t]{3}{*}{ Variables } & \multirow{2}{*}{\multicolumn{4}{|c|}{$\frac{\text { Fixed effects }}{\text { Fire season }(n=3)}$}} & \multicolumn{4}{|c|}{ Random effects } \\
\hline & & & & & \multicolumn{2}{|c|}{ Plot $(n=9)$} & \multicolumn{2}{|c|}{ Year $(n=4)$} \\
\hline & $F$ & $d f$ & $P$ value & $R^{2}$ & $x^{2}(1 d f)$ & $P$ value & $x^{2}(1 d f)$ & $P$ value \\
\hline Fire intensity ${ }^{a}$ & 7.17 & 2.33 & 0.003 & 0.30 & 0.00 & 1.000 & 2.27 & 0.132 \\
\hline Flame height & 16.17 & 2.33 & $<0.001$ & 0.49 & 0.01 & 0.925 & 1.83 & 0.176 \\
\hline Rate of fire spread ${ }^{a}$ & 11.78 & 2.33 & $<0.001$ & 0.42 & 0.01 & 0.912 & 1.57 & 0.210 \\
\hline Residence time $>60^{\circ} \mathrm{C}$ & 4.53 & 2. 24 & 0.021 & 0.27 & 0.00 & 1.000 & 1.34 & 0.247 \\
\hline Maximum temperature & 6.67 & 2.24 & 0.005 & 0.36 & 0.00 & 1.000 & 0.58 & 0.447 \\
\hline Combustion efficiency & 9.24 & 2.6 & 0.015 & & 4.49 & 0.034 & 0.00 & 1.000 \\
\hline Wind speed & 3.97 & 2.6 & 0.029 & & 0.00 & 1.000 & 35.59 & $<0.001$ \\
\hline Air temperature & 2.35 & 2.33 & 0.112 & 0.12 & 0.01 & 0.921 & 0.14 & 0.706 \\
\hline Air humidity & 3.55 & 2.33 & 0.040 & 0.18 & 0.00 & 1.000 & 2.83 & 0.093 \\
\hline Fuel load (fresh) & 23.14 & 2.30 & $<0.001$ & & 0.00 & 1.000 & 10.95 & $<0.001$ \\
\hline Fuel moisture content & 11.16 & 2.33 & $<0.001$ & 0.40 & 0.00 & 1.000 & 0.11 & 0.738 \\
\hline Grass height & 58.41 & 2.30 & $<0.001$ & & 0.00 & 1.000 & 15.01 & $<0.001$ \\
\hline
\end{tabular}

Mixed models analyses were performed with the $\mathrm{R}$ Imer function. $\mathrm{R}^{2}$ values provided for fixed-effects models when random effects were not significant. Boldface data indicates effects significant at the 0.05 level. $F=F$ value; $\mathrm{df}=$ degrees of freedom; $X^{2}=$ chi-squared statistic

${ }^{a}$ log-transformed prior to analysis based on the distribution of residuals.

fuel moisture decreased by $12 \%$ (for $10 \%$ of fuel humidity, fire intensity was $8800 \mathrm{~kW} \mathrm{~m}{ }^{-1}$; for $22 \%$ fuel humidity, $4430 \mathrm{~kW} \mathrm{~m}^{-1}$; and for $50 \%, 540 \mathrm{~kW} \mathrm{~m}^{-1}$ ).

Our results are also consistent with the conclusion of Govender et al. (2006), that the effects of seasonal moisture override that of fuel load. During the early dry season of our study, there were large quantities of live perennial fuel with high moisture content, but the fires had the lowest rate of spread, intensity, and flame height (Fig. 2).

According to Hoffmann et al. (2012), the microclimate during fire determines flammability because of its effect on fuel moisture. In our study, air humidity was the only weather parameter that varied between seasons (with a higher average value during the early fire; i.e, this variable did impact fire behavior). In dry conditions, fires were faster and more intense, flames were higher, but the maximum residence time was shorter.

Contrary to the reports from studies in other savannas that wind speed (Savadogo et al. 2007, Vega et al. 2012) and air temperature (Platt et al. 2015) strongly affect fire behavior, this was not the case in our study in the Guinean savanna of Lamto Reserve. These two parameters did not change over the seasons in our study, although fire behavior certainly did. A lack of effect of wind speed may be due to generally low wind speed in Lamto Reserve (Le Roux 1995), as was also reported in the Brazilian Cerrado (Rissi et al. 2017); further, there are only minor variations of air temperature throughout the year (Forge 1982).

Table 2 Prediction of fire behavior variables from weather and fuel variables

\begin{tabular}{|c|c|c|c|c|}
\hline Response and explanatory variables & s.e.e. & $R^{2}$ & $F$ & P-value \\
\hline $\log (h)=10.61-0.0589 F M^{* * *}-0.0187 \mathrm{AH}$ & 0.5701 & 0.55 & 14.89 & $<0.0001$ \\
\hline $\log (r)=0.8036-0.0717 F M^{* * *}-0.0191 A H^{*}$ & 0.5697 & 0.63 & 20.54 & $<0.0001$ \\
\hline$H=4.4963-0.0388 F M^{* * *}-0.0189 A H^{* *}$ & 0.3587 & 0.64 & 20.97 & $<0.0001$ \\
\hline$T=1028.161-73.324 G H-4.226 F M-3.466 A H^{*}$ & 105.967 & 0.45 & 6.41 & 0.002 \\
\hline$R t=0.8694-0.7908 F L^{* *}+0.0206 F M+0.0221 A H^{* *}+0.02496 A T$ & 0.7276 & 0.51 & 5.74 & 0.002 \\
\hline$C=106.755-6.452 G^{*}$ & 3.197 & 0.34 & 12.99 & 0.001 \\
\hline
\end{tabular}

Results show best models found by stepwise backward multiple regressions with plot and year as crossed random effects (using the $\mathrm{R}$ step function of the ImerTest package). Response (predicted) variables: fire intensity $(l)$, rate of fire spread $(r)$, flame height $(H)$, fire maximum temperature $(T)$, fire residence time above $60^{\circ} \mathrm{C}(R t)$, and combustion efficiency $(C)$. Explanatory (predictors) variables: fuel load $(F L)$, fuel moisture content $(F M)$, grass height $(G H)$, wind speed $(\mathrm{W})$, air humidity $(A H)$, air temperature $(A T)$. s.e.e. $=$ standard error of estimation; $\mathrm{R}^{2}=$ coefficient of determination; $F=F$ value

${ }_{* * * *}^{* *}<0.001$

${ }^{* *} P<0.01$

${ }^{*} P<0.05$

$P<0.1$

$P>0.1$ 
Our analyses indicating that seasonal fuel characteristics and weather conditions jointly contribute to determine fire behavior in these West African humid savannas is consistent with studies of Higgins et al. (2000) in southern African savannas, and Platt et al. (2015) in humid savannas of southeastern North America. In particular, in Lamto Reserve, fuel moisture and air humidity are highly predictive of fire behavior; these variables are relatively easily measured in the field. The models presented in this study are novel and could be useful tools for assessing and monitoring various fire regimes in the humid savannas of West Africa. To date, no other work is available that can be used to predict fire behavior in this region.

\section{Potential severity of fire}

In our study, although there was no difference in fire behavior between mid dry season and late dry season fires, there were differences in fire severity (e.g., the effect on trees) across seasons. Indeed, late-season fires are known to negatively impact trees in Lamto Reserve (Gignoux et al. 2006). Similarly, the high impact of late-season fires on trees is common in other savannas; most studies attribute this phenomenon to higher fire intensity (Williams et al., 1998, Savadogo et al. 2007).

We suggest that the differences in fire severity (impact on trees) between mid-season and late-season fires (despite similar fire behavior) is most likely explained by the phenological state of trees, as suggested for humid savannas in Australia (Werner and Prior 2013) and southeastern North America (Robertson and Hmielowski 2014). In Lamto Reserve savanna, all trees are leafless during the dry season so that mid-season fire cannot cause significant damage to living tree tissues (i.e., trunks and main branches are fire resistant (Gignoux et al. 1997, N'Dri et al. 2014). However, at the end of the dry season or beginning of the rainy season, trees begin to set new leaves, so that fire at this period could be very detrimental (Gignoux et al. 2009). In addition, the longer lethal temperature residence time during late-season fires compared to mid-season fires could further explain the high impact of late-seaon fire on trees.

Our results support the hypothesis that the generally observed high severity of late-season fires for savanna trees is not due to a higher fire intensity: we found no significant increase in fire intensity in late-season fires compared to mid-season fires. However, to assess this point further, studies are needed relating fire intensity to measures of tree growth and survival under different fire regimes.

\section{Conclusion}

In the humid savannas of Lamto Reserve that are representative of the Guinean savanna-forest mosaic ecoregion, up to 35 to $65 \%$ of the total variation of several metrics used to describe fire behavior can be predicted by fuel moisture and air humidity. Specific qualities of the site (e.g., very low wind speed on average) may limit generalization in the absence of a larger spatial and temporal data coverage, so further work using other sites is highly desirable. Among the various aspects of fire behavior, we recommend using flame height measurements, as it is easier to measure than intensity, in order to quickly produce large datasets that could help us to understand and predict fire behavior. The ultimate goal is to improve fire management in West Africa.

\section{Acknowledgements \\ We thank Y. Kolo, director of the Lamto Research Station, for field access and logistics. We thank H. Kounan and M. Konan for field assistance. Our gratitude also goes to S. Loisel for his technical input in the field work. We also thank the entire team, including the numerous students, of our project called GIDES (Gestion Intégrée et Durable des Ecosystèmes de Savane), for their help during the field work, their comments, and observations. We thank T. Charles- Dominique and A. Andersen for their contributions to the manuscript. The assistance of $\mathrm{P}$. Werner and two anonymous reviewers in improving earlier drafts of this paper is much appreciated.}

\section{Funding}

We thank IRD (Institut de Recherche pour le Développement) for funding this work through the JEAl (Jeune Equipe Assoicée) programme.

\section{Availability of data and materials}

We can't share our data because we are still using these data for modelization.

\section{Authors' contributions}

A.B. N'Dri, K. Dosso, M. Koné, N.A. Koné, and J.K. N'Dri conceived the study plot. T.D. Soro compiled the data. A.B. N'Dri, T.D. Soro, J. Gignoux, and S. Barot analyzed the data. A.B. N'Dri wrote the paper. J. Gignoux, S. Barot, K. Dosso, and N.A. Koné provided comments on a draft of the manuscript. All authors read and approved the final manuscript.

\section{Authors' information}

Aya Brigitte N'Dri is a lecturer at University of Nangui Abrogoua since 2012. She is a specialist in fire and plant ecology.

Kanvaly Dosso, Mouhamadou Koné, N'golo Abdoulaye Koné, and Julien Kouadio N'Dri are also lecturers and specialists in macrofauna and savanna ecology.

Tionhonkélé Drissa Soro is a PhD student in fire ecology.

Jacques Gignoux, and Sébastien Barot are specialists in plant ecology, biostatistics, and modelization.

Ethics approval and consent to participate

Not applicable

Consent for publication

Not applicable

\section{Competing interests}

The authors declare that they have no competing interests.

\section{Publisher's Note}

Springer Nature remains neutral with regard to jurisdictional claims in published maps and institutional affiliations.

\section{Author details}

'UFR des Sciences de la Nature, Station d'Ecologie de Lamto/CRE, Pôle de Recherche Environnement et Développement Durable, Université Nangui Abrogoua, 02 BP 801, Abidjan 02, Côte d'Ivoire. EES-Paris (CNRS, IRD, UPMC, INRA, UPEC, UP7), UPMC, 4 place Jussieu, 75252, cedex 05 Paris, France. 
${ }^{3}$ Unité de Formation et de Recherches en Sciences Biologiques, Université Peleforo Gon Coulibaly, BP 1328, Korhogo, Côte d'Ivoire.

\section{Received: 10 November 2017 Accepted: 3 July 2018} Published online: 30 August 2018

\section{References}

Abbadie, L., J. Gignoux, M. Lepage, X. Le Roux. 2006. Environmental constraints on living organisms. Pages 45-61 in: L. Abbadie, J. Gignoux, X. Le Roux, and M Lepage, editors. Lamto: structure, functioning, and dynamics of a savanna ecosystem. Springer Verlag, New York, New York, USA.

Afelu B, Kokou K (2015) Paramètres physiques d'évaluation du comportement des feux de végétation au Togo. International Journal of Biological and Chemical Sciences 9(4):2091-2105 [In French.] https://doi.org/10.4314/ijbcs. v9i4.31

Anderson SAJ, Anderson WR (2010) Ignition and fire spread thresholds in gorse (Ulex europaeus). International Journal of Wildland Fire 19:589-598 https://doi. org/10.1071/WF09008

Aubréville A (1953) Les expériences de reconstitution de la savane boisée en Côte d'Ivoire. Bois et Forêts des Tropiques 32:4-10 [In French.]

Brookman-Amissah J, Hall JB, Swaine MD, Attakorah JY (1980) A re-assessment of a fire protection experiment in northeastern Ghana savanna. Journal of Applied Ecology 17:85-99 https://doi.org/10.2307/2402965

Burrows ND (1995) A framework for assessing acute impacts of fire in jarrah forests for ecological studies. CALM Science Supplement 4:59-66

Byram, G.M. 1959. Combustion of forest fuels. Pages 61-89 in: K.P. Davis, editor. Forest fire: control and use. McGraw-Hill, New York, New York, USA.

Daniell JW, Chappell WE, Couch HB (1969) Effect of sublethal and lethal temperature on plant cells. Plant Physiology 44:1684-1689 https://doi.org/10. 1104/pp.44.12.1684

Dauget JM, Menaut JC (1992) Evolution sur 20 ans d'une parcelle de savane boisée non protégée du feu dans la réserve de Lamto (Côte d'Ivoire). Candollea 47:621-630 [In French.]

Dwomoh FK, Wimberly MC (2017) Fire regimes and their drivers in the upper Guinean region of West Africa. Remote Sensing 9(11):1117 https://doi.org/10. 3390/rs9111117

Fontaine JB, Vanessa CW, Enright NJ, Lade JC, Miller BP (2012) Fire behaviour in south-western Australian shrublands: evaluating the influence of fuel age and fire weather. International Journal of Wildland Fire 21:385-395 https:// doi.org/10.1071/WF11065

Forge P (1982) Nouvelle approche de la définition des saisons climatiques de la région de Lamto (Côte d'Ivoire). Annales de l'Université d'Abidjan XV:7-25 [ln French.]

Frost PGH, Medina E, Menaut JC, Solbrig O, Swift M, Walker BH (1986) Responses of savannas to stress and disturbance. Biology International Special Issue 10:1-82

Gautier L (1990) Contact forêt-savane en Côte d'Ivoire centrale: evolution du recouvrement ligneux des savanes de la réserve de Lamto (sud du V baoulé). Candollea 45:627-641 [In French.]

Gignoux, J., S. Barot, J.C. Menaut, and R. Vuattoux 2006. Structure, long term dynamics and demography of the tree community. Pages 335-364 in: L. Abbadie, J. Gignoux, X. Le Roux, and M. Lepage, editors. Lamto: structure, functioning and dynamics of a savanna ecosystem. Springer-Verlag, New York, New York, USA. https://doi.org/10.1007/978-0-387-33857-6_18

Gignoux J, Clobert J, Menaut JC (1997) Alternative fire resistance strategies in savanna trees. Oecologia 110:576-583 https://doi.org/10.1007/s004420050198

Gignoux J, Lahoreau G, Julliard R, Barot S (2009) Establishment and early persistence of tree seedlings in an annually burned savanna. Journal of Ecology 97:484-495 https://doi.org/10.1111/j.1365-2745.2009.01493.x

Gignoux, J., P. Mordelet, and J.C. Menaut. 2006. Biomass cycle and primary production. 115-137 in: L. Abbadie, J. Gignoux, X. Le Roux, and M. Lepage, editors. Lamto: structure, functioning and dynamics of a savanna ecosystem. Ecological studies, 179. Springer-Verlag, New York, New York, USA. https:// doi.org/10.1007/978-0-387-33857-6_7

Gill AM, Allan G (2008) Large fires, fire effects and the fire-regime concept. International Journal of Wildland Fire 17:688-695 https://doi.org/10.1071/ WF07145

Govender N, Trollope WSW, van Wilgen BW (2006) The effect of fire season, fire frequency, rainfall and management on fire intensity in savanna vegetation in South Africa. Journal of Applied Ecology 43:748-758 https://doi.org/10. $1111 / j .1365-2664.2006 .01184 . x$
Guiguindibaye M, Belem MO, Boussim Jl (2013) Caractéristiques des feux dans un incendie en savane soudanienne au Tchad. International Journal of Biologica and Chemical Sciences 7(3):1147-1156 [In French.] https://doi.org/10.4314/ ijbcs.v7i3.21

Higgins S, Bond W, Trollope WSW (2000) Fire, resprouting and variability: a recipe for grass-tree coexistence in savanna. Journal of Ecology 88:213-229 https:// doi.org/10.1046/j.1365-2745.2000.00435.x

Hochberg ME, Menaut JC, Gignoux. J (1994) The influences of tree biology and fire in the spatial structure of the West African savanna. Journal of Ecology 82(2):217-226 https://doi.org/10.2307/2261290

Hoffmann WA, Jaconis S, McKinley KL, Geiger EL, Gotsch SG, Franco AC (2012) Fuels or microclimate? Understanding the drivers of fire feedbacks at savanna-forest boundaries. Austral Ecology 37:634-643 https://doi.org/10. 1111/j.1442-9993.2011.02324.x

Innes RR (1972) Fire in West African vegetation. Tall Timbers Fire Ecology Conference Proceedings 11:147-173

Kidnie S, Wotton BM (2015) Characterisation of the fuel and fire environment in southern Ontario's tallgrass prairie. International Journal of Wildland Fire 24: 1118-1128 https://doi.org/10.1071/WF14214

Kier G, Mutke J, Dinerstein E, Ricketts TH, Kuper W, Kreft H, Barthlott W (2005) Global patterns of plant diversity and floristic knowledge. Journal of Biogeography 32:1107-1116 https://doi.org/10.1111/j.1365-2699.2005.01272.x

Laris P, Koné M, Dadashi S, Dembele F (2017) The early/late fire dichotomy: time for a reassessment of Aubréville's savanna fire experiments. Progress in Physical Geography: Earth and Environment 41:68-94 https://doi.org/10. $1177 / 0309133316665570$

Le Roux, X. 1995. Survey and modelling of water and energy exchanges between soil, vegetation and atmosphere in a Guinea savanna. Dissertation, Université de Paris, France.

L'Hôte, Y., and G. Mahé. 2012. Annual rainfall map of Africa. French Research Institute for Development, Marseille, France.

Louppe D, Ouattara N, Coulibaly A (1995) The effects of bush fires on vegetation: the Aubreville fire plots after 60 years. Commonwealth Forestry Review 74(4): 288-292

Morrison DA (2002) Effects of fire intensity on plant species composition of sandstone communities in the Sydney region. Austral Ecology 27:433-441 https://doi.org/10.1046/.1442-9993.2002.01197.x

N'Dri AB, Gignoux J, Barot S, Konaté S, Dembélé A, Werner P (2014) The dynamics of hollowing in annually burnt savanna trees and its effect on adult tree mortality. Plant Ecology 215:27-37 https://doi.org/10.1007/s11258013-0276-9

N'Dri AB, Gignoux J, Konaté S, Dembélé A, Aïdara D (2011) Origin of trunk damage in West African savanna trees: the interaction of fire and termites. Journal of Tropical Ecology 27:269-278 https://doi.org/10.1017/S026646741000074X

Pagney, P. 1988. Le climat de Lamto (Côte d'Ivoire). Pages 31-79 in: M. Lamotte and J.L. Tireford, editors. Le climat de la cavane de Lamto (Côte d'Ivoire) et sa place dans les climats de l'Ouest Africain. Travaux de Recherche des Chercheurs de Lamto, Côte d'Ivoire, Afrique de l'Ouest. [In French.].

Platt WJ, Orzell SL, Slocum MG (2015) Seasonality of fire weather strongly influences fire regimes in South Florida savanna-grassland landscapes. PLoS ONE 10(1):e0116952 https://doi.org/10.1371/journal.pone.0116952

Prichard SJ, Stevens-Rumann CS, Hessburg PF (2017) Tamm review: shifting global fire regimes: lessons from reburns and research needs. Forest Ecology and Management 396:217-233 https://doi.org/10.1016/j.foreco.2017.03.035

R Development Core Team (2014) R: a language and environment for statistical computing. R Foundation for Statistical Computing, Vienna, Austria

Rissi MN, Baeza MJ, Gorgone-Barbosa E, Zupo T, Fidelis A (2017) Does season affect fire behaviour in the Cerrado? International Journal of Wildland Fire 26:427-433

Robertson KM, Hmielowski TL (2014) Effects of fire frequency and season on resprouting of woody plants in southeastern US pine-grassland communities. Oecologia 174:765-776 https://doi.org/10.1007/s00442-013-2823-4

Savadogo P, Zida D, Sawadogo L, Tiveau D, Tigabu M, Odén PC (2007) Fuel and fire characteristics in savanna-woodland of West Africa in relation to grazing and dominant grass type. International Journal of Wildland Fire 16:531-539 https://doi.org/10.1071/WF07011

Sidzabda DD, Savadogo P, Zida D, Sawadogo L, Tiveau D, Odén PC (2010) Fire temperature and residence time during dry season burning in a Sudanian savanna-woodland of West Africa with implication for seed germination. Journal of Forestry Research 21(4):445-450 https://doi.org/10.1007/s11676010-0095-y 
Smit IPJ, Asner GP, Govender N, Vaughn R, van Wilgen BW (2016) An examination of the potential efficacy of high-intensity fires for reversing woody encroachment in savannas. Journal of Applied Ecology 53(5):16231633 https://doi.org/10.1111/1365-2664.12738

Spichiger R, Pamard C (1973) Recherches sur le contact forêt-savane en Côte d'Ivoire: etude du recrû forestier sur des parcelles en lisières d'un îlot forestier dans le Sud du pays Baoulé. Candolllea 28:21-37 [In French.]

Swaine MD, Hawthorne WD, Orgle TK (1992) The effects of fire exclusion on savanna vegetation at Kpong, Ghana. Biotropica 24(2):166-172 https://doi. org/10.2307/2388670

Swetnam TW, Allen CD, Betancourt JL (1999) Applied historical ecology: using the past to manage for the future. Ecological Applications 9(4):1189-1206

Trollope, W.S.W. 1983. Control of bush encroachment with fire in the arid savannas of south-eastern Africa. Dissertation, University of Natal, Pietermaritzburg, South Africa.

Trollope, W.S.W., L.A. Trollope, and D.C. Hartnett. 2002. Fire behaviour a key factor in the ecology of African grasslands and savannas. Paper 204 in: D.X. Viega, editor. Forest fire research and wildland fire safety: proceedings of IV international conference on forest fire research 2002 wildland fire safety summit, Luso, Coimbra, Portugal, 18-23 November 2002, Millpress, Rotterdam, Netherlands.

van Wilgen BW, Govender N, Biggs HC (2007) The contribution of fire research to fire management: a critical review of a long-term experiment in the Kruger National Park, South Africa. International Journal of Wildland Fire 16:519-530 https://doi.org/10.1071/WF06115

van Wilgen BW, Le Maitre DC, Kruger FJ (1985) Fire behaviour in South African fynbos (macchia) vegetation and predictions from Rothermel's fire model. Journal of Applied Ecology 22:207-216 https://doi.org/10.2307/2403338

van Wilgen, B.W., W.S.W. Trollope, H.C. Biggs, A.L.F Potgieter, and B.H. Brockett. 2003. Fire as a driver of ecosystem variability. Pages 149-170 in: J.T. du Toit, K.H. Rogers, and H.C. Biggs, editors. The Kruger experience: ecology and management of savanna heterogeneity. Island Press, Washington, D.C., USA

Vega JA, Jiménez E, Dupuy JL, Linn RR (2012) Effects of flame interaction on the rate of spread of heading and suppression fires in shrubland experimental fires. International Journal of Wildland Fire 21:950-960 https://doi.org/10. 1071/WF10124

Vuattoux R (1976) Contribution à l'étude de l'évolution des strates arborée et arbustive dans la savane de Lamto (Cote d'Ivoire). Deuxieme note. Annales de l'Universite d'Abidjan, série C 7(1):35-63 [In French.]

Werner PA, Prior LD (2013) Demography and growth of subadult savanna trees: interactions of life history, size, fire season, and grassy understory. Ecological Applications 83(1):67-93 https://doi.org/10.1890/12-1153.1

Williams RJ, Gill AM, Moore PHR (1998) Seasonal changes in fire behaviour in a tropical savanna in Northern Australia. International Journal of Wildland Fire 8(4):227-239 https://doi.org/10.1071/WF9980227

\section{Submit your manuscript to a SpringerOpen ${ }^{\circ}$ journal and benefit from:}

- Convenient online submission

- Rigorous peer review

- Open access: articles freely available online

- High visibility within the field

- Retaining the copyright to your article

Submit your next manuscript at $\boldsymbol{\nabla}$ springeropen.com 